\title{
The Role of Leadership Style in Applying Improvement Culture to Employee Performance through Motivation as an Intermediary Variable at University of Sumatra Utara
}

\author{
Fivi Rahmatus Sofiyah ${ }^{1}$, Ritha F. Dalimunthe ${ }^{2}$ \\ ${ }^{1,2}$ Department of Management, University of Sumatera Utara, Medan, Indonesia. \\ Corresponding Author: Fivi Rahmatus Sofiyah
}

\begin{abstract}
This study aims to determine and explain: the description of the role of leadership styles at University of Sumatera Utara through motivating the application of Kaizen culture to employee performance. The type of research used in this research is an explanatory research using quantitative methods. The variables in this study are: leadership style and improvement culture as independent variables, work motivation as the mediating variable, and employee performance as the dependent variable. This research uses primary data in the form of responses to the questionnaire, as well as secondary data obtained through documents. The data analysis method used is path analysis. The results of path analysis show that: leadership style variables have a positive and significant impact on employee performance, Leadership style variables have a positive and significant impact on motivation, Kaizen cultural variables have a positive and significant impact on employee performance, Kaizen cultural variables have a positive and significant impact on motivation, and motivation variables have significant effects on employee performance. Influence; the leadership style variables have a positive and significant impact on employee performance through motivation; the improvement of culture has a positive and significant impact on employee performance through motivation.
\end{abstract}

Keywords: Leadership Style, Kaizen Culture, Employee Performance, Motivation

\section{INTRODUCTION}

Human resources are one of the most important parts of a company's organization, because human resources play a leading role in the company's activities. Even today, many companies have used advanced technologies in their business activities, but without the active participation of employees, all these advanced technologies will be useless. In today's era of globalization, companies are required to always improve their performance and productivity. One way to achieve this goal is to improve the production process. The improvement of the production process needs to be carried out continuously to minimize wasted materials and time.

Mangkunegara (2009) pointed out that performance is the work done by employees to achieve expected goals. Employee performance is a factor that affects how much they contribute to the organization. The performance improvement of individuals and groups has become the focus of work to improve organizational performance (Mathis \& John, 2000). Performance is the description of the achievement of an activity/plan/policy implementation in achieving the organization's goals, objectives, vision and mission (Mahsun, 2006).

Personal performance, motivation and employee retention are the main factors for organizations to maximize the 
effectiveness of their personal resources (Mathis and Jackson, 2011). Motivation is something that cannot be separated from company performance, so it can be said that motivation is related to performance. Working according to the motivation of employees will make them happy at work, happy to work, with a sense of belonging, desire for achievement and desire for creativity, which will have an impact on improving employee performance (Umar, 2011).

In the company, there must be a leader who can assist the company in achieving its goals. According to Robbins (2015), leadership is the ability to influence a team to achieve a predetermined vision or goal. The company needs an effective leadership style in order to be able to improve the performance of all employees in order to achieve the goals set by the company. In addition to leadership styles, the success of an organization or company in achieving its goals may also be affected by the culture of improvement.

Improvement is a targeted, structured continuous improvement process. The success of the improvement makes many companies hope to apply the improvement to their company (Marcpherson, 2015). The main goal of improvement is to eliminate waste-from a consumer's point of view, waste does not increase the value of the product/service. The existence of organizational culture in the company will greatly help the company achieve its goals. Culture is a term that is difficult to express clearly, but everyone can appreciate its existence (Rahmi, 2014).

According to Nurma, Harjono and Hariyani (2017) in their research, the impact of cultural Kaizen on PT Bank BCA employee performance is that cultural Kaizen affects employee performance. In this research, cultural Kaizen uses the $5 \mathrm{~S}$ concept (Seiri, Seiton, Seiso, Qingchi and Jingchi). Hakim, Al Musadieq, and Nurtjahjono (2017) conducted research on PT Semen Indonesia Tbk employees. In addition to research on World Bank employees, they also obtained results that the adoption of Kaizen culture affects employee performance. It can be seen from this research that Kaizen culture is an organizational culture that can be applied to all types of companies. On the basis of the above discussion, the author is interested in conducting research at Sumatera Utara University, and proposed the research title "The Role of Leadership Style in Sumatera Utara University by Motivating the Application of Cultural Improvement Methods to Employee Performance"

\section{LITERATURE REVIEW}

1. Literature review should be written here with proper citation. Leadership Style

According to the statement of Kartono (2008): "Leadership style is the distinctive nature, habits, temperament, character and personality of a leader when interacting with others. According to Thoha (2010), leadership style is a person's attempt to influence others or subordinates. The code of conduct used in the behavior.

According to the above concept of leadership style, it can be concluded that leadership style is the ability of leaders to guide, influence, encourage and control their subordinates so that they can work hard for their own consciousness and voluntarily achieve a certain goal.

\section{Kaizen Culture}

Cultural work culture is a philosophy based on the view of life as values. These values have become traits, habits and driving forces, rooted in the lives of community groups or organizations, and embodied in behaviors, beliefs, thoughts, opinions, and Behavioral attitude. According to Prasetya (2002), it is expressed as work or work. Japanese work culture is called improvement.

According to Imai (2008), "improvement" is "continuous progress and improvement of people's lives, family life, community life, and work life". At the same time, according to Wellington (1998), "improvement" is "a simple concept 
Fivi Rahmatus Sofiyah et.al. The role of leadership style in applying improvement culture to employee performance through motivation as an intermediary variable at University of Sumatra Utara.

consisting of two characters, namely: improvement means change, Zen means good, so when combined into a word, its literal It means "improve". The term "Kaizen" is used in Ardiasyah (2013), and is interpreted as "kaizen" is an umbrella concept that includes some typical Japanese customs that have recently become widespread around the world. Kato and Art Smalley (2011) pointed out that there are 6 steps to improvement. The six steps can be seen in the figure below: 1. Find potential improvements 2 . Analyze current methods 3. Introduce original ideas 4. Develop an implementation plan 5. Implement a plan 6. Evaluate new methods

\section{Employee}

Performance comes from the concept of performance. Others define performance as the result of work or job performance. However, performance actually has a broader meaning, not only the result of work, but also how the work process occurs (Wibowo, 2007). Maluyu SP Hasibuan (2011) pointed out: "Performance (work performance) is the result of a person performing the tasks assigned to him based on skills, experience, seriousness and time." Employee performance is a factor that affects how much they contribute to the organization. The performance improvement of individuals and groups has become the focus of work to improve organizational performance. According to the definition of Mangkunegara (2006), performance is "work refers to the quality and quantity that an employee obtains in performing his duties according to his assigned responsibilities". The quality mentioned here is seen from the refinement, cleanliness and accuracy of the work, while the quantity is seen from the amount of work or workload that employees must complete.

\section{Motivation}

This theory comes from the viewpoint of Abraham Maslow. Explain that the required human needs are layered. This means that if the first requirement is met, then the second requirement will appear, and so on. Masag in Siagian (2007) explained that the needs to be met will stop their motivation. Mc Clelland is very interested in Murray's expressed need, which is the need for achievement. Because achievement is learned and obtained from an early age from the nature of the parents' personal desires.

\section{MATERIALS \& METHODS}

Method used in this research is descriptive quantitative research methods. The variables in this study are latent variables consisting of kaizen culture, leadership style and employee performance and motivation, and manifest variables consisting of indicators on each latent variable. After the variables used are identified, the preparation of a questionnaire which is an instrument in this study is carried out with a measurement scale from 1 to 5. The next stage is data collection, either through distributing questionnaires or interviews with related parties, questionnaires are distributed to 120 respondents which are then analyzed. using path analysis.

\section{RESULT}

Result of this study uses path analysis to evaluate the Role of Leadership Style in the application of Kaizen Culture to Employee Performance through Motivation at University of Sumatera Utara.

Table 1.Path Coefficients

\begin{tabular}{|c|c|c|}
\hline & T Statistics & P Values \\
\hline Leadership Style -> Employee performance & 6,548 & 0,000 \\
\hline Leadership Style -> Motivation & 2,943 & 0.003 \\
\hline Motivation -> Employee performance & 4,318 & 0,000 \\
\hline Kaizen culture_-> Employee performance & 6.63 & 0,000 \\
\hline kaizen_culture -> Motivation & 29,052 & 0,000 \\
\hline Leadership Style -> Motivation -> Employee performance & 2,211 & 0.027 \\
\hline kaizen_culture $->$ Motivation $->$ Employee performance & 4,168 & 0,000 \\
\hline
\end{tabular}


Fivi Rahmatus Sofiyah et.al. The role of leadership style in applying improvement culture to employee performance through motivation as an intermediary variable at University of Sumatra Utara.

\section{DISCUSSION}

Based on the table above, it explains that:

1. Leadership Style has a positive and significant effect on Employee Performance $(p=0.00<0.05)$ then $\mathrm{HO}$ is rejected $\mathrm{H} 1$ is accepted, It means that there is a direct influence between leadership style and employee performance. According to the research of Dania et al. (2012), the leadership style indicators used include idealized influence, motivational inspiration, intellectual development and personal attention. Bath et al. (2003) pointed out that transformational leadership style is a leadership style that can touch the superior and subordinate value system, thereby creating an environment conducive to improving employee performance. Dvir et al. (2002) also pointed out that there is a positive influence between transformational leaders and the potential development of subordinates.

2. The results of this study are different from previous studies. In the results of this study, leadership style has a negative impact on employee performance, while the previous study, Siradjuddin (2007) conducted a study, leadership style has a positive impact on employee performance. Leadership theory points out that the manager's leadership style will directly affect the effectiveness of the working group (Kreitner and Kinicki, 2005) (Tris Nanning, 2007). The theory is based on the idea that making an organization effective depends on the behavior/style of the leader. The leader's success in making the organization more effective depends on his behavior in fulfilling his leadership functions

3. Leadership Style has a positive and significant effect on motivation $(\mathrm{p}=$ $0.03<0.05$ ), so $\mathrm{H} 0$ is rejected. $\mathrm{H} 1$ is accepted, meaning that there is a direct influence between Leadership Style and Motivation. According to Bass in
Septiana (2013), a leader with a transactional leadership style can provide motivation for subordinates, involving exchange relationships between subordinates by exchanging remuneration for the work done. The ability to influence leaders will determine how employees achieve work results. Therefore, it will be able to increase work power from always maintaining good working conditions. The results of this study are consistent with Cloud (2014), which shows that transactional leadership has a positive effect on work motivation.

4. Motivation has a positive and significant effect on employee performance $(\mathrm{p}=$ $0.00<0.05$ ), so $\mathrm{H} 0$ is rejected, $\mathrm{H} 1$ is accepted, meaning that there is a direct influence between motivation and employee performance. The results of this study are the same as previous studies, namely the study conducted by Ma'rifah (2005), which shows that work motivation has a positive effect on employee performance. In addition, the results of this study are the same as those conducted by Narmodo et al. (2005) showed that motivation has a positive and significant impact on employee performance. In theory, the use of effective and targeted labor is the key to improving company performance. Therefore, company policies need to be formulated to mobilize their labor so that they are willing to work more efficiently according to the company's plan.

5. Kaizen culture has a positive and significant effect on employee performance ( $p=0.00<0.05)$, so $\mathrm{HO}$ is rejected, $\mathrm{H} 1$ is accepted, meaning that there is a direct influence between Kaizen culture and employee performance. The Wellington view of Nurma et al. (2000). al (2017) believes that Kaizen's principle is: empowering employees means providing skills and opportunities to apply the information provided. Through various skills 
training, encouragement, decisionmaking responsibilities, access to data sources and budgets, feedback and rewards, employees has the right to exert significant influence on themselves and the company's activities. Working in improvement is to improve the status quo with the support of innovation and creativity to improve performance. The results of this study also support the findings of Rohman (2016), Mulyawati (2015) and Hakim et al. (2016), who pointed out that improving culture has a positive impact on employee performance. Therefore, it can be concluded that continuous improvement culture has an impact on making employee performance a high performance.

6. Kaizen culture has a positive and significant effect on motivation ( $\mathrm{p}=$ $0.00<0.05$ ), so $\mathrm{H} 0$ is rejected. $\mathrm{H} 1$ is accepted, meaning that there is a direct influence between Kaizen culture and motivation. According to Cheser (1998), the transformation of American manufacturing from traditional methods to Japanese improvements has achieved a significant increase in productivity. Although the improvement has obviously adopted scientific management techniques, this transformation also seems to have brought a wealth of work and greater motivation. The results show that improvements increase job richness and employee motivation, and may enable employees to achieve higher levels of growth power that require growth.

7. Leadership Style has a positive and significant effect on Employee Performance through Motivation ( $\mathrm{p}=$ $0.02<0.05)$ so $\mathrm{H} 0$ is rejected $\mathrm{H} 1$ is accepted, meaning that there is an indirect influence between Leadership Style on Employee Performance through Motivation. The results of this study are consistent with previous research conducted by Septiana (2013), which showed that motivation has been shown to play a mediating role in the relationship between transaction leadership and performance. The leadership style possessed by a leader has been proven to affect employee performance. Motivation has been shown to play an intermediary role in the relationship between transactional leadership and performance (Septiana, 2013). Therefore, the hypothesis that can be formed is H6: Transactional leadership has a positive impact on motivation-mediated employee performance.

8. Kaizen culture has a positive and significant effect on employee performance through motivation $(\mathrm{p}=$ $0.00<0.05$ ), so $\mathrm{H} 0$ is rejected, $\mathrm{H} 1$ is accepted, meaning that there is an indirect effect between Kaizen culture on employee performance through motivation. The results of this study are the same as the previous study, that is, the study conducted by Mohammad Ariful Hakim et al. (2016) titled "Improving Culture's Impact on Motivation and Performance" ("PT Indonesia Semen Indonesia Company Employee Research"), the result is that the applied variables of improving culture have a significant impact on motivation. Work and the application of improved culture also have a significant impact on employee performance.

\section{CONCLUSION}

Based on the discussion of the above research results, it can be concluded:

1. Leadership style has a positive and significant impact on employee performance $(\mathrm{p}=0.00<0.05)$, and then reject $\mathrm{H} 0$ and accept $\mathrm{H} 1$, which means that there is a direct relationship between leadership style and employee performance.

2. Leadership style has a positive and significant impact on motivation $(\mathrm{p}=$ $0.03<0.05$ ), so $\mathrm{H} 0$ is rejected. $\mathrm{H} 1$ is accepted, which means that there is a 
Fivi Rahmatus Sofiyah et.al. The role of leadership style in applying improvement culture to employee performance through motivation as an intermediary variable at University of Sumatra Utara.

direct influence between leadership style and motivation.

3. Motivation has a positive and significant impact on employee performance $(\mathrm{p}=$ $0.00<0.05$ ), so $\mathrm{H} 0$ is rejected and $\mathrm{H} 1$ is accepted, which means that there is a direct relationship between motivation and employee performance.

4. Kaizen culture has a positive and significant impact on employee performance $(\mathrm{p}=0.00<0.05)$, so $\mathrm{H} 0$ is rejected and $\mathrm{H} 1$ is accepted, which means that there is a direct impact between Kaizen culture and employee performance.

5. Kaizen culture has a positive and significant impact on motivation $(\mathrm{p}=$ $0.00<0.05$ ), so $\mathrm{H} 0$ is rejected. $\mathrm{H} 1$ is accepted, which means that there is a direct influence between Kaizen's culture and motivation.

6. Leadership style has a positive and significant impact on employee performance through motivation $(\mathrm{p}=$ $0.02<0.05$ ), so reject $\mathrm{H} 0$ and accept $\mathrm{H} 1$, which means that leadership style has an indirect impact on employee performance through motivation.

7. Kaizen culture has a positive and significant impact on employee performance through incentives $(\mathrm{p}=$ $0.00<0.05$ ), so $\mathrm{H} 0$ is rejected and $\mathrm{H} 1$ is accepted, which means that Kaizen culture has an indirect impact on employee performance through incentives.

\section{SUGGESTIONS}

From the results of the research, data analysis, discussion and conclusions that have been drawn, the following suggestions can be made:

1. The University of North Sumatra must first study the applied improvement culture so that leaders can more easily adapt to employees and provide employees with direct insights so that they can work better. And thank the employees for their performance.
Acknowledgement: None

Conflict of Interest: None

\section{Source of Funding: None}

\section{REFERENCES}

1. AA Anwar Prabu Mangkunegara, 2009. Human resource management. Rosdakarya youth. Bandung.

2. Abraham Maslow, 2009, New Paradigm of Resource Management, As the Basis for Achieving Competitive Advantage, Yogyakarta; Econisia.

3. Anjani, Siti Rahmi. (2014). Implementation of Democracy Education through Civics Learning to Form Responsible Citizens. Bandung: Indonesian Education University.

4. Bass, et.al.. (2003). Predicting unit performance by assessing transformational and transactional leadership. Journal of Applied Psychology. Vol. 88, No. 2, pp. 207-218

5. Cheser, Raymond N. International Journal of Organizational Analysis; Bowling Green Vol. 6, Iss. 3, (Jul 1998): 197-217.

6. DS Syahreza, P Lumbanraja, RF Dalimunthe, Y Absah (2017) Compensation, employee performance, and mediating role of retention: A study of differential semantic scales. European Research Studies Journal Volume XX, Issue 4A, 2017. pp. 151-159

7. Dvir. 2002. Taly Dvir Impact ofTransformasional Leadership on Follower Development and Performance: A Field Experiment. AMJ Press. pp. 4.

8. Hasibuan, Malayu SP, 2011. Human Resource Management. Jakarta: PT Bumi Askara.

9. Husein, Umar. 2011. Research Methods for Thesis and Business Thesis Edition 11. Jakarta: PT Raja Grafindo Persad

10. Imai, Masaaki. 2008. The Kaizen Power translated by Sigit Prawato. Jogjakarta: Think.

11. Kartono, Kartini, 2008: Leader and Leadership. Jakarta: PT. Raja Grafindo Persada.

12. Kreitner dan Kinichi. 1998. Organization Behavior. Boston,Irwin. McGraw-Hill,

13. L,S. Marina; et.al. The Effect Of Learning Organizations, Achievement Motivation Through Work Environment As A 
Fivi Rahmatus Sofiyah et.al. The role of leadership style in applying improvement culture to employee performance through motivation as an intermediary variable at University of Sumatra Utara.

Moderating Variable On The Job Satisfaction Of Temporary Employees' (Non Medical) In The Administration Service Of North Sumatra University Hospital Medan, Indonesia. European Journal of Human Resource Management Studies, [S.1.], aug. 2019. ISSN 26011972. Available.

http://dx.doi.org/10.46827/ejhrms.v0i0.604.

14. Mahsun, Mohamad. 2006. Public Sector Performance Measurement: First Edition. Yogyakarta: Publisher BPFE-Yogyakarta.

15. Mathis, Robert L, and Jhon H Jackson, 2000.Human Resources Management $10^{\text {th }}$ edition, Tomson South-Western, United States

16. Ma'rifah, Dewi, 2005, Pengaruh Kinerja dan Budaya Organisasi Terhadap Kinerja Pekerja Sosial Pada Unit Pelaksanaan Dinas Sosial Propinsi Jawa Timur, Jurnal Manajemen dan Bisnis, universitas Air Langga, Surabaya.

17. Mulyawati, F. 2015. Pengaruh Budaya Kaizen terhadap Kinerja Karyawan PT. Gistex Garmen Indonesia. http://repository.widyatama.ac.id/xmlui/han dle/123456789/6287. (Diakses 1Juli 2017).

18. Mohamamad Ariful Hakim, M. A. 2016. Pengaruh Budaya Kaizen terhadap Motivasi dan Kinerja,Studi pada Karyawan PT Semen Indonesia Tbk. Jurnal Administrasi Bisnis (JAB), Vol. 35 No. 1 Juni 2016.

19. McPherson, F. (2015, 097$)$. About memory. Retrieved 11 06, 2015, from the powered: http://www.memorykey.com/memory/emotion

20. Mohammad et.al. 2016. The Influence of Kaizen Culture on Motivation and Performance (Study on Employees of PT Semen Indonesia Tbk). Malang: Journal of Business Administration (JAB) | Vol. 35 No. June 1, 2016

21. Nurma et.al. 2017. Analysis of the Influence of Kaizen Culture on Employee Performance at PT. Bank Central Asia, Tbk
Pangkalpinang Main Branch Office (Case Study at PT Bank Central Asia Pangkalpinang Main Branch Office). Progressive Journal of Business Management (JPMB). Vol 18 (2), 12 p. Available: https://jurnal.stie-ibek.ac.id

22. Prasetya, Triguno. 2002. Human Resource Management. Jakarta: Bumi Aksara

23. Robbins, Stephen. 2015. Organizational Behavior. 9th Edition. New Jersey: Precentice Hall International Inc.

24. Rohman, M. 2016. Pengaruh Budaya Kaizen terhadap Kinerja Karyawan MPM Insurance Palembang. http://repo.iba.ac.id/index.php?p=fstreampdf \&fid=417\&bid=954Skripsi. $\quad$ (Diakses 1 Juli 2017).

25. Smalley A, Isao K. 2011. Toyota Kaizen Methods. Jakarta: Gradient Mediatama.

26. Thoha Miftah., (2010), Organizational Development, process of diagnosis and intervention, Leadership Management. Yogyakarta, Gava Media.

27. Trisnaningsih, S., 2007. Independensi dan Komitmen Organisasi sebagai Mediasi Pengaruh Pemahaman Good Governance, Gaya Kepemimpinan dan Budaya Organisasi terhadap Kinerja Auditor. Makasar: SNA X.

28. Wellington, Patricia. 1998. Kaizen Strategy for Customer Care. Translated by Alexander Sindiro. Batam: Interaksara

29. Wibowo. (2007). Work management. Third edition. Jakarta: PT. Raja Grafindo Prasada

How to cite this article: Sofiyah FR, Dalimunthe RF. The role of leadership style in applying improvement culture to employee performance through motivation as an intermediary variable at University of Sumatra Utara. International Journal of Research and Review. 2021; 8(4): 92-98. DOI: https://doi.org/10.52403/ijrr. 20210414 